\title{
Relationship Between Students' Grades and School Year and Their Intention for Entrepreneurship: Some Pioneering Findings ${ }^{1}$
}

\author{
Narendra C. Bhandari
}

\begin{abstract}
his is the first study of its kind to explore the relationship between students' year of education and their

intention to start a business once they have completed their undergraduate studies. The article also examines students' cumulative grade point average and their intention to start a business once they have completed their undergraduate studies. These pioneering findings are based on an extensive title review (including their summaries) of bundreds of articles related to these factors listed in EBSCO.
\end{abstract}

Keywords: Lubin School students; year of education; cumulative grade point average; undergraduate studies

This article determines whether there is a relationship between the Lubin School students' current year of education and their cumulative grade point average and their intention to start a business once they have completed their undergraduate studies. This analysis also looks at the statistical relationship between the students' cumulative grade point average and their intention to start a business once they have completed their undergraduate education.

\section{Research Methodology ${ }^{2}$}

A six-page questionnaire containing 91 questions (variables) was designed for this study, which was distributed among selected undergraduate students at the Lubin School of Business, Pace University, New York, during the December 2004-December 2005 period. $^{3}$

Copies of the questionnaire were sent to the author's faculty colleagues who agreed to allow their students to participate in the study. Of the 435 responses completed by the students, 390 were included for further analysis. Forty-five of these were found unusable for the study for various reasons.

\section{Purpose of Research}

The overall purpose of this continuing research is to determine whether there is a statistical relationship between a number of independent variables and Lubin School of Business students' intentions to become entrepreneurs after they have completed their undergraduate education.

This article is limited to analyzing selected variables as stated in the following hypotheses:

H1a. Null Hypothesis: There is no statistical difference between the Lubin students' current year of undergraduate education (first, second, third, or fourth year) - and their intention to start a business once they have completed their undergraduate studies.

H1b. Alternate Hypothesis: There is such a statistical difference.

H2a. Null Hypothesis: There is no statistical difference between the Lubin students' cumulative grade point average as of the preceding semester (As, $\mathrm{Bs}, \mathrm{Cs}$, or lower than Cs)-and their intention to starting a business once they have completed their undergraduate studies.

H2b. Alternate Hypothesis: There is such a statistical difference.

The independent variables (students' year of education and students' cumulative grade point average) were tested against the dependent variable (intention to become entrepreneur). Figure 1 lists the exact questions related to these variables as included in the questionnaire.

\section{Limitations of Study}

This is a study of the Lubin students who were taking undergraduate business courses (accounting, information system, management, or marketing) at different class levels (first, second, third, or fourth year) during the study period. The 390 students chosen for the study were all different individuals. This is not a study of the same individuals as they progressed from their first year of study through to their fourth year.

\footnotetext{
${ }^{1}$ This is an adaptation of the article presented by the author at the Academy of International Business Northeast (AIBNE)'s 2012 Annual Conference; and published by the AIBNE in its Proceedings (pages 268-276).

${ }^{2}$ Much of material presented in this section is identical to Bhandari (2012).

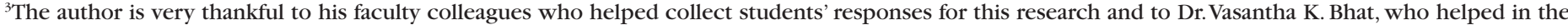

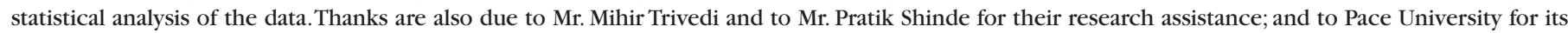
support of this study.
} 


\section{Independent Variables}

9. What is your current year of education (check one):
(a) 1st year of undergraduate study
(b) 2nd year of undergraduate study
(c) 3rd year of undergraduate study
;(d) 4th year of undergraduate study
(e) 1st year of graduate study
;(f) 2nd year of graduate study

12. What is your cumulative grade point average as of the preceding semester/term (check one):
(a) $\mathrm{A}+, \mathrm{A}, \mathrm{A}-$
(b) $\mathrm{B}+, \mathrm{B}, \mathrm{B}-$
; (c) $\mathrm{C}+, \mathrm{C}, \mathrm{C}-$
; (d) Lower than C

\section{Dependent Variable}

15. After you have finished your education (whether you have attained a degree or not), what do you intend to do (check one):

a. Start my own business

b. Work for a business owned by an immediate family member (spouse, parent, brother and/or sister)

c. Work for someone else

Figure 1. List of Independent and Dependent Variables Used for Research (with Their Original Question Numbers)

\section{Definition, Requirements, and Education}

This following sections provide a brief overview of the definition, requirements, and educational aspects of entrepreneurship.

\section{Entrepreneurship Definition}

According to Wikipedia, the free Encyclopedia, the term "entrepreneur" first appeared in the Dictionnaire Universal de Commerce, Jacques des Bruslons' French dictionary, published in 1723. In English, the term applies to a person who is willing to help launch a new venture or enterprise and accept full responsibility for the outcome (Wikipedia 2012). Other definitions include the following:

-1934: Schumpeter: Entrepreneurs are innovators who use a process of shattering the status quo of the existing products and services, to set up new products, new services (Wikipedia 2012).

- 1961: David McClleland: An entrepreneur is a person with a high need for achievement [N-Ach]. He is energetic and a moderate risk taker (Wikipedia 2012).

- 1964: Peter Drucker: An entrepreneur searches for change, responds to it, and exploits opportunities. Innovation is a specific tool of an entrepreneur; hence an effective entrepreneur converts a source into a resource (Wikipedia 2012).

- According to a European Commission report (2008), "entrepreneurship refers to an individual's ability to turn ideas into action. It includes creativity, innovation, and risk taking, as well as the ability to plan and manage projects in order to achieve objectives."

\section{Entrepreneurs: Born or Made}

Like the traits theory of leadership that argues leaders are born and cannot be made, there are those who contend that entrepreneurs are also born and cannot be educated and trained to become them.

Birch said that if you want to teach people to be entrepreneurs, you can't. To them, entrepreneurship, like leadership, is a function of some invisible personality attributes (in Aronsson 2004). According to Thompson (2004, quoted in Fayolle 2008), talent and temperament cannot be taught.

On the other hand, Peter Drucker noted that "It is becoming clear that entrepreneurship, or certain facets of it, can be taught. Business educators and professionals have evolved beyond the myth that entrepreneurs are born not made. The entrepreneurship is not magic, it's not mysterious, and it has nothing to do with the genes. It's a discipline. And, like any discipline, it can be learned" (Drucker 1985 in Kuratko 2005).

I maintain that entrepreneurship, like leadership, is a function of certain skills and attitudes that can be acquired and improved upon through education and experience. If one can learn to become a medical doctor, he or she can also learn to become an entrepreneur. Actually, it is sometimes easier to become an entrepreneur than to be qualified as a physician or physicist. If Birch were opining today, I am sure he would have entirely different thoughts.

\section{Entrepreneurship Education}

The merits of entrepreneurial education have been cited by several people. Entrepreneurship education could help students establish and manage a business properly. It could also help them prepare for working for someone else.

In a 2009 article describing an academic program focusing on innovation and entrepreneurship at a French engineering school, students' educational activities were studied to assess how they wanted to attain their goals (either by creating a firm, or by being creative within an existing firm), as well as 
how they create connections, form partnerships outside established fields, organize the distribution of tasks, and receive financial support, among others (Mustar 2009).

The significance of an entrepreneurship education is evidenced by the fact that a growing number of institutions, other than the business schools, are offering courses and programs in the various fields of entrepreneurship. These include, among others, the schools of arts, engineering, medicine, nursing, and sciences.

In its March 2008 report, the European Commission recommended that the teaching of entrepreneurship should be integrated in more curricula, not just in the curricula of business or economic studies.

\section{Research Findings and Discussion}

Several statistical techniques, such as chi-square, regression analysis, and t-test, are available to test the validity of a set of data. Only the chi-square technique has been used to test the validity of data used in this research because the data gathered amply satisfied the following four primary assumptions of the Pearson's chi-squared test: (1) independence of observations, (2) large enough expected cell counts, (3) randomness of data, and (4) sufficient sample size (Yates, Moore, and McCabe, 1999).

\section{Research Findings}

A summary of the statistical analysis of data related to the two hypotheses is presented in Figure 2. The figure also shows the decisions reached based on this analysis.

This analysis endorses the acceptance of the Null Hypothesis 1a: That there is no statistical difference between the students' current year of education (first/second/ third/fourth year) - and the students' intention to start a business once they have completed their undergraduate studies. The calculated value of $\mathrm{X}^{2}, 1.61729$, is smaller than the tabulated value of $\mathrm{X}^{2}, 9.49$, with 3 degrees of freedom with alpha $=.05$.

This analysis also endorses the acceptance of the Null Hypothesis 2a: That there is no statistical difference between the students' cumulative grade point average-and their intention to start a business once they have completed their undergraduate studies. The calculated value of $\mathrm{X}^{2}, 2.18879$, is smaller than the tabulated value of $\mathrm{X}^{2}, 7.82$, with 3 degrees of freedom with alpha $=.05$.

\section{Discussion}

This is the first study of its kind to explore the relationship between (a) students' year of education and their intention to start a business once they have completed their undergraduate studies and (b) students' cumulative grade point average and their intention to start a business once they have completed their undergraduate studies. My claim about these pioneering findings is based on an extensive title review (including their summaries) of hundreds of articles related to these factors listed in EBSCO.

Due to the lack of similar studies to review and compare, the survey of literature presented below is limited to a study of some other variables that reflect upon the students' intention for entrepreneurship.

In his study of students at a university in India, Bhandari (2006) found that "luck" and "to lead other people" have a statistical relationship with the intention to start their own

\begin{tabular}{|c|c|c|c|c|c|c|}
\hline Null Hypothesis & $\begin{array}{c}\text { Total No. } \\
\text { of Respondents }\end{array}$ & $\begin{array}{c}\text { No. of Respondents } \\
\text { Who Want to be } \\
\text { Entrepreneurs }\end{array}$ & $\begin{array}{c}\mathrm{X}^{2} \\
\text { Calculated } \\
\text { Value }\end{array}$ & $\begin{array}{c}\mathrm{X}^{2} \\
\text { Critical } \\
\text { Value }\end{array}$ & $\begin{array}{l}\text { Degree of } \\
\text { Freedom, } \\
\mathrm{a}=.05\end{array}$ & $\begin{array}{c}\text { Decision on } \\
\text { Null Hypothesis }\end{array}$ \\
\hline $\begin{array}{l}\text { There is no } \\
\text { relationship between } \\
\text { Students' Current year } \\
\text { of education } \\
\text { (1st year to 4th year) } \\
\text { and Their Intention } \\
\text { for Entrepreneurship }\end{array}$ & 391 & 177 & 1.61729 & 9.49 & 3 & Accept \\
\hline $\begin{array}{c}\text { There is no relationship } \\
\text { between Students' } \\
\text { Cumulative GPA } \\
\text { and Their Intention } \\
\text { to Become } \\
\text { Entrepreneurs }\end{array}$ & 380 & 169 & 2.18879 & 7.82 & 3 & Accept \\
\hline
\end{tabular}

Figure 2. Relationship between Selected Variables and Students' Intention for Entrepreneurship 
business after completing education.

In another study of students at Pace University's Lubin School of Business, Bhandari (2012) noted that there is no statistical difference between these students' gender and their intention to start a business once they have completed their undergraduate studies.

Research by Wilson et al. (2004 in Shinnar, Pruett, and Toney 2009) also concluded that men expressed higher entrepreneurial interest than did women, a relation that was consistent across Hispanic, black, and white youth (Wilson et al. 2004).

In a study of secondary school students enrolled in the Young Achievement Australia (YAA) enterprise program, Peterman and Kennedy (2003) found that the participants, after completing the enterprise program, reported significantly higher perceptions of both desirability and feasibility of starting a business.

According to Crispeels et al. (2008), the drive toward (or away from) entrepreneurship comes from the potential entrepreneur's perception of his or her own skills and the environment. The more confident the potential entrepreneur is about these factors, the more likely the step toward nascent entrepreneurship becomes.

\section{Suggestions for Research}

This research shows that Lubin School of Business students' intention to become entrepreneurs is not related to their undergraduate year of education (first, second, third, or fourth year). Likewise, their cumulative grade point average has no statistical relationship with their intention to become entrepreneurs.

The following are suggestions for further research:

1. Relationship between grades and intention for entrepreneurship among undergraduate/graduate-level students enrolled in the various areas of business such as, accounting, economics, finance, insurance, management, and marketing.

2. Relationship between grades and intention for entrepreneurship among undergraduate/graduate-level students enrolled in the various areas of English, geography, history, law, mathematics, and philosophy.

3. Relationship between grades and intention for entrepreneurship among undergraduate/graduate-level students enrolled in the various areas of science, technology, engineering, and mathematics.

4. Relationship between grades and intention for entrepreneurship among undergraduate/graduate-level students enrolled in the various areas of medicine and nursing.

5.The intention for entrepreneurship of the "same" students as they progress from their first year to their second, third, and fourth years of college.

6.The intention for entrepreneurship of the "same" students as they progress from their first, second, third, and fourth years of undergraduate education and, if they continue, through their graduate years of education.

\section{References}

Aronsson, Magnus (2004). "Education Matters-But Does Entrepreneurship Education? An interview with David Birch," Academy of Management Learning and Education, 3, 3: 289-292.

Bhandari, Narendra C. (2006). "Intention for Entrepreneurship among Students in India,"Journal of Entrepreneurship, July-December.

Bhandari, Narendra C. (2012). "Relationship between Students' Gender, Their Own Employment, Their Parents' Employment, and the Students' Intention for Entrepreneurship," Journal of Entrepreneurship Education, 15: 133-144. Published online.

Crispeels, Thomas, Oliver Uecke, Marc Goldstein, and Michael Schefczyk (2008). "Best Practices for Developing University BioEntrepreneurship Education Programmes," Journal of Commercial Biotechnology 15: 136-150. Published online.

Drucker, P. F. (1985). Innovation and Entrepreneurship. New York: Harper \& Row.

European Commission (March 2008). Entrepreneurship in Higher Education, Especially in Non-Business Studies, page 10.

Fayolle,Alain (2008). "Entrepreneurship Education at a Crossroads:Towards a More Mature Teaching Field," Journal of Enterprising Culture, 16, 4: 325-337.

Kuratko, Donald F. (2005). "The Emergence of Entrepreneurship Education: Development, Trends, and Challenges," Entrepreneurship Theory \& Practice: 586-597.

Mustar, Philippe (2009). "Technology Management Education: Innovation and Entrepreneurship at Mines ParisTech, a Leading French Engineering School," Academy of Management Learning E Education, 8, 3: 418-425.

Peterman, Nicole E., and Jessica Kennedy (2003). "Enterprise Education: Influencing Students' Perceptions of Entrepreneurship," Entrepreneurship Theory \& Practice. 
Shinnar, Rachel, Mark Pruett, and Bryan Toney (2009). "Entrepreneurship Education:Attitudes Across Campus," Journal of Education for Business, 84, 2: 151-159.

Thompson, John. L. (2004). "The Facets of the Entrepreneur: Identifying Entrepreneurial Potential. Management Decision, 42, 2: 243-258.

Wikipedia, the Free Encyclopedia, accessed August 19, 2012.

Wilson, F., D. Marlino, and J. Kickul (2004). "Our Entrepreneurial Future: Examining the Diverse Attitudes and Motivations of Teens across Gender and Ethnic Identity, Journal of Developmental Entrepreneurship, 9, 177-197.

Yates, Daniel, David Moore, and George McCabe (1999). The Practice of Statistics. W. H. Freeman.

\section{About the Author}
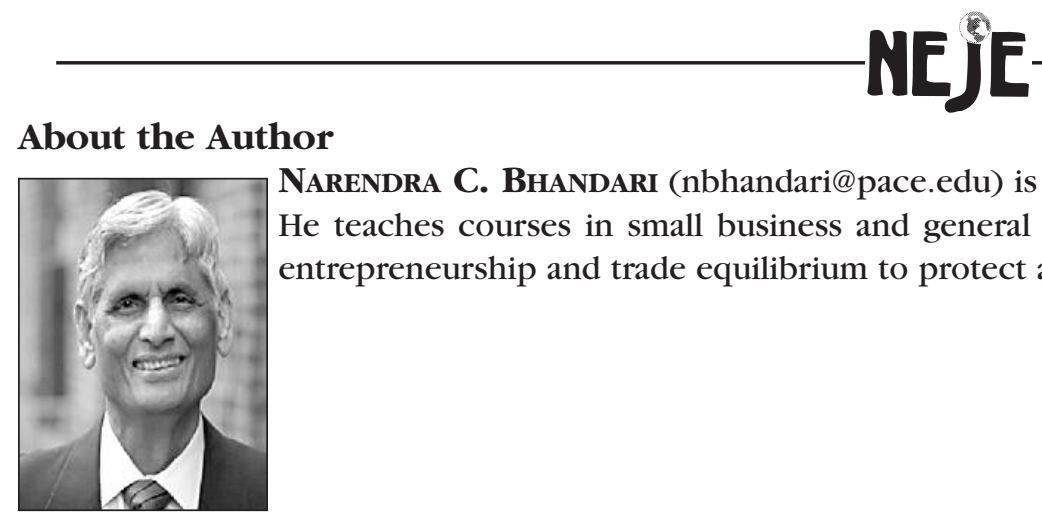

NARENDRa C. Bhandari (nbhandari@pace.edu) is a Professor of Management at Pace University, New York. He teaches courses in small business and general management. His research interests include the areas of entrepreneurship and trade equilibrium to protect and create jobs. 